\title{
Utforskende dialoger om to ungdomsromaner
}

\author{
Åsmund Hennig \\ Universitetet $i$ Stavanger
}

\begin{abstract}
Sammendrag
Artikkelens formål er å undersøke hvordan elever initierer og utvikler sekvenser av utforskende dialog i elevstyrte litterære samtaler om to ungdomsromaner fra fritidskulturen. Bakgrunn for artikkelen er blant annet et ønske om bedre å forstå hvordan antatt interesse for og innlevelse i selvvalgte fritidstekster påvirker substansen i elevers litterære samtaler. Artikkelens empiriske grunnlag er analyser av lydopptak av litterære samtaler gjennomført av to grupper av elever på niende trinn, som del av en treårig studie av omfattende bruk av litterære samtaler på ungdomstrinnet. Det teoretiske grunnlaget består av transaksjonsteori (Jeffrey D. Wilhelm), teori om litterære samtaler og utforskende dialog (Harvey Daniels, Nancy Steineke, Neil Mercer, Douglas Barnes). Analysens sentrale funn er at utforskende dialoger her i hovedsak initieres av elevenes interesse for og innlevelse i de fiktive personenes mimetiske komponent og utvikles gjennom utveksling av perspektiver som også berører de fiktive personenes tematiske komponent. Elevenes skolering i litterære samtaler framstår også som en sentral medvirkende faktor.
\end{abstract}

Nøkkelord: Utforskende dialog; littercere samtaler; litterer respons; ungdoms fritidstekster

\begin{abstract}
Exploratory talk about YA-fiction

The purpose of the article is to investigate how students initiate and develop sequences of exploratory talk in student-led literature circles aboutYA-fiction. The article seeks better understanding of how perceived interest in self-selected leisure texts affects the substance of students' literature circles. The empirical basis for the article is analysis of audio recordings of literature circles conducted by two groups of students in grade 9, as part of a three-year study of extensive use of literature circles at secondary school. The theoretical basis consists of transaction theory (Jeffrey D. Wilhelm), theory of literature circles and exploratory talk (Harvey Daniels, Nancy Steineke, Neil Mercer, Douglas Barnes). The central findings of the analysis are that exploratory talk is mainly initiated by the pupils' interest and immersion in the mimetic component of the fictional characters and is developed through the exchange of perspectives that also touch on the thematic component of the characters. Students' education in literature circles also appears to be a key contributing factor.
\end{abstract}

Keywords: Exploratory talk; literature circles; literary response; $Y A$-fiction

Gjesteredaktører: Gudrun Kløve Juuhl og Maja Michelsen

Received: December, 2019; Accepted: October, 2020; Published: December, 2020

^Korrespondanse: Åsmund Hennig, e-post: asmund.hennig@uis.no

(C) 2020 Åsmund Hennig. This is an Open Access article distributed under the terms of the Creative Commons Attribution 4.0 International License (https://creativecommons.org/licenses/by-nc/4.0/), allowing third parties to copy and redistribute the material in any medium or format and to remix, transform, and build upon the material for any purpose, even commercially, provided the original work is properly cited and states its license.

Citation: A. Hennig. "Utforskende dialoger om to ungdomsromaner" Nordic fournal of Literacy Research, Special issue: Barn og unges tekstpraksier i fritiden, 6(3), 2020, 136-151. http://dx.doi.org/10.23865/njlr.v6.2071 


\section{Innledning og problemstilling}

«Det er liksom hvilke type valg mennesker har, og hvor mye de bestemmer over seg selv.» Ei jente på fjorten bøyer seg ivrig fram over bordet, mens hun gjør en betraktning om den individuelle frihetens betingelser $i$ et strengt regulert samfunn. Sammen med to medelever diskuterer hun en dystopisk ungdomsroman de selv har valgt. Særlig spennende er det hvilke valg hovedpersonen Cassia vil gjøre. Hun må nemlig gjøre mange valg, både konkrete valg i møte med umiddelbar fare, moralske valg i overganger til nye livsfaser, og ikke minst et romantisk valg mellom to beilere. Elevenes innlevelse i personene og handlingen er intens, og en viktig drivkraft for den utforskingen og refleksjonen de sammen gjør gjennom samtalen. Dessuten er de godt skolerte i litterære samtaler, noe som også gir samtalen flyt og retning. De tre går i en klasse som er én av fire klasser på niende trinn som siden starten av åttende trinn hadde vært med på et større forskningsprosjekt om langvarig og systematisk bruk av litterære samtaler. Et sentralt mål for prosjektets involverte forskere og lærere var å undersøke undervisningssituasjoner som både ga rom for elevenes egne innspill og tolkninger, og for å kunne gi elevene mer spesifikke tilbakemeldinger, basert på håndterlige analysekategorier. Denne artikkelen analyserer og diskuterer to gruppers litterære samtaler om selvvalgte ungdomsromaner, og undersøker hvordan sekvenser av utforskende dialog blir initiert og kommer til uttrykk i samtalene. Sentralt i undersøkelsene står da hvordan elevene presenterer leseresponser som kan initiere sekvenser av utforskende dialog og hvordan elevene eventuelt følger opp med ulike former for samtaleresponser som kan videreutvikle sekvenser av utforskende dialog. Artikkelen vil da inkludere en vurdering av mulige mønstre i elevenes dialogiske aktivitet, i disse sekvensene.

\section{Teoretiske og metodiske perspektiver}

Det teoretiske utgangspunktet for artikkelen er at en leser av litterære tekster beveger seg gjennom det Jeffrey D. Wilhelm kaller ti ulike responsformer, gruppert $\mathrm{i}$ interessevekkende, konnektive og reflekterende dimensjoner (2008). Wilhelm bygger på Judith A. Langers beskrivelse av en hermeneutisk prosess der leseren, ved hjelp av forestillingsevnen, etablerer en forestillingsverden bestående av mentale bilder, tanker og følelser (Langer, 1995, s. 9ff). Langer tar utgangspunkt i Louise M. Rosenblatts forståelse av litterær lesing som en konstruktiv, selektiv prosess i en spesifikk kontekst (Rosenblatt, 1995, s. 26), som vi vel kan mene er et fundament for transaksjonsteorien. Den interessevekkende dimensjonen innebærer at leseren først trer inn i fortellingens verden, blir stadig mer interessert og etablerer forhold til de fiktive personene. De konnektive responsformene innebærer at leseren elaborerer en forestillingsverden ved å gjøre en rekke ulike forbindelser innad i teksten og mellom teksten og verden. Responsformenes reflekterende dimensjon innebærer så et mer abstrahert blikk, der leseren deretter blant annet vurderer tekstens ulike siders betydning, forfatterens virksomhet og leserens eget bidrag som leser i transaksjonen 


\section{A. Hennig}

med teksten (Wilhelm, 2008, s. 61ff; Wilhelm \& Novak, 2011, s. 77ff). Trolig aktiveres de interessevekkende responsformene særlig i elevenes møte med de fiktive personene som mimetiske størrelser. James Phelan identifiserer tre sentrale tekstkomponenter spesifikke for fiksjonsprosa: (a) Den syntetiske komponenten avdekker konstruksjonen og understreker det fiktive; "the character as artificial construct». (b) Personens mimetiske komponent består av de trekkene som giør at man, gjerne over tid, danner seg et bilde av "denne bestemte (fiktive) personen"; "the character as person». (c) Ved den tematiske komponenten finner vi at den fiktive personen også fungerer som et tegn som inngår i en større helhet av andre intensjonale tegn, og slik representerer en tanke eller en mening; "the character as idea» (Phelan, 1989, s. 2-3, 1996, s. 29). Inndelingen er et nyttig verktøy, som vi her vil bruke for å identifisere elevenes analytiske fokus.

\section{Utforskende dialog}

I samtaleteorien vil det som gjerne kalles for utforskende dialog innebære at gjennom en kritisk utveksling av tanker utvikles en større og mer eller mindre felles forståelse av for eksempel en tekst. Observasjoner og ideer deles og utsettes for felles vurdering og utprøving. Utfordringer av framsatte perspektiver blir saklig begrunnet, og alternativer blir framsatt. Prosessen innebærer forsøk på å nå en form for enighet som fornuftig fundament for utvikling for alle involverte (Mercer, 2000, s. 98). Samtidig vil den enkelte leserens individuelle perspektiv alltid være utgangspunktet, og utforskende dialog innebærer derfor å kunne innta også andre perspektiver, både til andre deltakere i samtalen, til de fiktive personene og til forfattere (Ivey, 2014). Følgelig er utforskende dialoger også avhengig av ulike ståsteder, oppfatninger eller ideer, og av vilje til å utfordre hverandres perspektiver. Divergens brukes konstruktivt for videre dialog, blant annet gjennom refleksjon over egne perspektiver (Mercer, 2000, s. 98; Pierce \& Gilles, 2008). Utforskende dialoger vil også være karakterisert av et visst engasjement. Det er nødvendig for å drive samtalen videre gjennom problemstillinger og uklarheter. På den måten kan samtaledeltakerne i fellesskap oppdage mønster og mulige løsninger. Hypoteser blir konstruert om sentrale elementer i emnet som utforskes, og disse blir videre utprøvd og derav forkastet eller videre utviklet. Slik innebærer utforskende dialog etablering av ny innsikt (Pierce $\&$ Gilles, 2008).

De aller fleste litterære samtaler vil bestå av ulike sekvenser, med stor variasjon i for eksempel intensitet, engasjement og faglig utforsking. I lys av de her presenterte momentene vil sekvenser av utforskende dialog da bli forstått som spesifikke og tematisk sammenhengende deler av en samtale, som innledes med en leserespons, altså en ytring som framsetter et perspektiv, gjerne i form av forestillingsverden, observasjoner og ideer, og som følges opp i form av engasjerte samtaleresponser, altså andre samtaledeltakeres respons på den innledende ytringen, i form av blant annet bekreftelser, utvidelser, alternativer, vurderinger og utprøvinger. Utvekslingen av leseresponser og samtaleresponser vil sammen etablere ny innsikt. Sekvensen vil vare til den enten renner ut i mindre faglig prat, eller til et annet perspektiv innleder 
en ny sekvens. Overgangen mellom sekvensene kan være både i form av brudd og overlapping.

\section{Samtaler om selvvalgte ungdomsromaner}

Det overliggende målet for forskningsprosjektet som denne artikkelens samtaler inngår i, var å forstå bedre hvordan elevers litterære kompetanse og litterære faglighet utvikler seg når store deler av elevenes litteraturundervisning over lang tid blir organisert rundt elevstyrte litterære samtaler. I alt seks klasser (én på mellomtrinnet, resten på ungdomstrinnet), med til sammen rundt 150 elever, og syv lærere var involvert i prosjektet. To klasser var involvert i to år, mens fire klasser var med i prosjektet fra og med åttende til og med tiende trinn. Fire pilarer sto sentralt: (a)Vedvarende skolering av lærerne og elevene i litterære samtaler som teori og metode, gjennom gjensidig utveksling av kunnskap og erfaringer; (b) gjennomføring av et stort antall litterære samtaler om en så stor variasjon som mulig av tekster og teksttyper; (c) analyser av samtalene for å klargjøre elevenes litterære faglighet; (d) respons til elevene på grunnlag av slike analyser og med videreutvikling av elevenes litterære kompetanse og litterære faglighet som mål.

Et sentralt moment i det metodologiske fundamentet for forskningsprosjektet handlet om å gjøre bruk av det didaktiske potensialet som lesing av og samtaler om elevers selvvalgte tekster gir. Det er godt dokumentert at vi alle leser mer engasjert tekster vi har valgt selv (Allan et al., 2005, s. 5-6; Allington \& Gabriel, 2012, s. 10; Atwell \& Merkel, 2016, s. 124; Department for education, 2012, s. 3, 16; Edmunds \& Bauserman, 2006, s. 417; Gambrell, 2011, s. 175; Sanden, 2012, s. 225). Med ungdom som intenderte lesere presenterer fritidstekster estetiske erfaringer bestående av blant annet spenning, identifikasjonsmuligheter, refleksjonsaktiverende problemstillinger samt tydelige innslag av gjenkjennelige motiver og struktur. Følgelig er det ofte tekster som samsvarer med leseutviklingsfasen eller -fasene den intenderte leseren vil befinne seg i. En leser på fjorten år vil gjerne befinne seg i en overgang mellom det J. A. Appleyard kaller leseren som helt eller heltinne, der nettopp det repeterende, gjenkjennelige og spennende står sentralt (Appleyard, 1991, s. 61ff), og den tenkende leseren, med en interesse for tekster som er realistiske og tankevekkende og med personer det er mulig å identifisere seg med, men som samtidig er både engasjerende og underholdende (Appleyard, 1991, s. 101ff).

Samtalene om de selvvalgte ungdomsromanene ble gjennomført tidlig på våren, og de fire norsklærerne på trinnet hadde brukt juleferien til å orientere seg i et stort antall ungdomsromaner fra fritidskulturen for å finne fram til aktuelle tekster med størst mulig appell til forskjellige lesere. Selvsagt kan man diskutere hvordan man i det hele tatt avgjør hva slags tekster som tilhører ungdoms fritidskultur. For det første forholder ikke alle ungdom seg til de samme tekstene, på langt nær. For det andre er det ingen skarpe grenser mellom tekster som blir lest på eller utenfor skolen. Hovedkriteriet for lærernes utvalg av tekster var derfor ikke mer spesifikt enn at det skulle være romaner som de mente, etter grundige vurderinger, at det var sannsynlig at flere 


\section{A. Hennig}

eller noen av elevene selv valgte eller ville kunne velge å lese på fritiden. Man kan også diskutere hvor reelt valget til elevene var, da de ulike romanene ble presentert for dem. Men også det er del av en lagt større diskusjon, all den tid tekstbruken til barn og unge alltid er avhengige av valg som allerede er gjort av for eksempel forfattere, forleggere, distributører eller bibliotekarer - alle voksne. For elevene i dette prosjektet var det først og fremst et poeng at de kunne velge mellom et relativt stort antall titler med appell, noe som var en vesentlig utvidelse av den undervisningsrammen de vanligvis forholdt seg til ved valg av tekst.

I alt valgte de rundt 110 elevene omtrent 20 ulike titler. Tre av titlene ble lest av to grupper. I hver gruppe var det følgelig mellom tre og fem elever, og hver gruppe gjennomførte tre eller fire samtaler om teksten. Hovedprinsippet var at hver gruppe fikk nok tid til å organisere og gjennomføre lesing av og samtaler om hele romanen, noe de giorde med nokså god margin.

I denne artikkelen er det ikke en intensjon å undersøke hvorfor noen samtaler kan ha mer innslag av utforskende dialoger enn andre. Derfor var det heller ikke aktuelt eller naturlig å velge samtaler med tilsynelatende få innslag av utforskende dialog. Kjønnsfordeling var heller ikke et viktig kriterium, selv om det er interessant å sammenlikne en gruppe med tre jenter som leste en del på fritiden, med tre gutter som leste lite. Viktigere var samtalenes karakter, sett i lys av de to tekstenes nokså ulike form og innhold. Jentegruppen leste og samtalte om Cassias valg (2011) av Ally Condie, en framtidsdystopi der spenning og romantikk står sentralt. De gjennomførte tre samtaler om romanen. Guttene leste og samtalte om Sangen om en brukket nese (2012) av Arne Svingen, en roman om omsorgssvikt, savn og personlig seier. De gjennomførte fire samtaler om romanen. Begge romanene går inn i kjente fortellingsmønster fra liknende fritidstekster. Likevel konstruerer de svært ulike implisitte lesere. Det dystopiske aspektet i Cassias valg tematiserer blant annet ung fortvilelse i konfrontasjon med styresmaktenes despoti og renkespill. Heltens ulike valgprosesser blir også relatert til et romantisk trekantdrama, som i sum appellerer til lesernes egne vurderinger: Hvilke valg ville de gjort, hvis de sto i Cassias situasjon? Sangen om en brukket nese appellerer sterkt til lesernes empati. Det er en fortelling om hvordan et barn, i voksnes fysiske eller mentale fravær, må ta på seg en rolle som omsorgsperson. Samtidig er det også en fortelling om mekanismene i sosiale hierarki blant barn og unge, og om identitetsutvikling gjennom mer eller mindre selvstendige valg, med påfølgende tap og seire. De to romanene inviterer følgelig begge til innlevelse i og refleksjon over hovedpersonenes grunnleggende valg, samtidig som disse valgsituasjonene er svært ulike. De har da også ført til to ulike samtalerekker.

\section{Analyseprosessen}

Samtalene ble giennomført som en del av den normale norskundervisningen, og organisert av lærerne. Elevene var på dette tidspunktet godt vant med både litterære samtaler, bruk av rolleark og med å gjøre lydopptak av samtalene. Rolleark eller rollekort er en arbeidsform der elevene $\mathrm{i}$ en gruppe blir gitt hver sin oppgave når de leser 
teksten de skal samtale om, for eksempel å lage et sammendrag, finne viktige setninger eller avsnitt, formulere noen spørsmål, lage en tegning basert på teksten eller finne forbindelser mellom elementer i teksten og for eksempel andre tekster. Elevers og læreres vurderinger i etterkant av bruk av lydopptak viser at opptakene i all hovedsak, med noen naturlige individuelle variasjoner, påvirker samtalene lite (Hennig, 2019), noe de her analyserte samtalene synes å bekrefte. Som en del av forskningsprosjektet om langvarig og systematisk bruk av litterære samtaler, ble lydopptakene opprinnelig transkribert og analysert ved hjelp av analysekategorier som har til hensikt å fange opp litterær faglighet, slik den kommer til uttrykk i litterære samtaler. Dette er kategorier som blant annet bygger på Wilhelms teori om leseprosessens responsformer (Wilhelm, 2008), Langers teori om fortløpende vurdering (Langer, 1995, s. 94ff), og Daniels' og Robert E. Probsts prinsipper for konstruktiv vurdering av litterære samtaler (Daniels, 2002, s. 185ff; Probst, 2004, s. 249ff). Disse kategoriene kan samles i fem hovedgrupper. Den første gruppen sier noe om hvordan elevene hver for seg etablerer en forestillingsverden, som de så videreutvikler gjennom samtalens utveksling av perspektiver. Den andre hovedgruppen består av kategorier som fanger opp samtalens dynamikk slik den blir karakterisert av vekslingen mellom leseresponser og samtaleresponser. Kategoriene i den tredje hovedgruppen er ment å fange opp innslag av analyse og tolkning, mens om og hvordan elevene relaterer tekstens form og innhold til verden utenfor teksten blir vurdert ved hjelp av kategoriene i fjerde gruppe. De siste kategoriene retter oppmerksomheten mot elevens metakognisjon, for eksempel hvordan de reflekterer over egen lesing.

Også de syv samtalene her ble først analysert ved bruk av disse kategoriene for å få et generelt bilde av elevenes litterære faglighet, slik den kommer til uttrykk i samtalene. På grunnlag av disse analysene, og med utgangspunkt i denne artikkelens interesse, ble samtalene videre undersøkt i lys av teori om utforskende dialog. Etter hvert som visse mønster begynte å synliggjøre seg, og i en slags eksplorativ tilnærming, ble fire nye orienteringspunkter utviklet. Oppmerksomheten ble da rettet mot hvordan elevene: (a) presenterer egne perspektiver i form av respons på teksten (leserespons); (b) responderer spørrende og konstruktivt på andre deltakeres leseresponser (samtalerespons); (c) utveksler og begrunner saklig leseresponser og samtaleresponser, og utvikler slik større og felles forståelse og ny innsikt; (d) er engasjerte og forsøker å overkomme det uklare og det vanskelige.

\section{Analyser og drøftinger}

\section{Cassias valg}

Den første samtalen gruppen har om Cassias valg er karakterisert av den store interessen de viser for romanen allerede før de begynner å lese, ikke minst fordi de har lest liknende tekster tidligere, slik som for eksempel The Hunger Games og Divergent. Dette innebærer at de trer inn i fortellingen med klare forventninger til romanens plott, miljø og personer. Deretter drives mye av samtalen av ønsket om å finne ut hva 


\section{A. Hennig}

som kommer til å skje videre, ut over den delen de faktisk har lest til nå. De er da særlig opptatt av hovedpersonens rolle som kommende leder for frigiøringskampen mot samfunnet despotiske ledelse, og av det romantiske trekantdramaet som hovedpersonen også er en del av. Denne engasjerte diskusjonen fortsetter i de to neste samtalene, og fører etter alt å dømme til at de utvikler rike forestillingsverdener. En viktig forklaring på engasjementet er at det er en spenningsroman som avsluttes med en cliffhanger som viser fram til neste bok i serien.

Gruppen har forberedt seg til den første samtalen ved hjelp av såkalt rolleark, og har valgt rollene sammenfatter, illustratør og lysmester. Samtalen innledes av sammenfatteren (J1) som gir uttrykk for stor innlevelse i den romantiske spenningen som er i ferd med å utspille seg. Likedan konkretiserer illustratøren (J2) sin innlevelse ved hjelp av en omfattende og detaljert tegning, som hun også verbalt forklarer og utdyper detaljert og utfyllende.

J2: Ok, jeg har tegnet en jente, eller Cassia da på en måte, i et bur. Det ser ut som et fuglebur da, men det er liksom et bur, og rundt er det alle de hverdagslige tingene som hun liksom holder på med. [...] Og det jeg prøver å si med dette, er at det er at samfunnet bestemmer liksom alt om henne. Så hverdagen hennes er liksom det myndighetene har bestemt. [...] Det synes jeg er ganske dårlig måte å styre samfunnet på. Fordi de føler at de ikke får vist sin personlighet og gjøre det de liker selv. Og de blir på en måte tvunget i sitt eget liv. Ja. (CV, samtale 1, 01:31-02:45)

Til tross for et visst preg av parafrase, vitner tegningen og forklaringen om en rik forestillingsverden, selv så tidlig i leseprosessen, der J2 aktiverer både en interessevekkende responsform, som innebærer å se fortellingens verden ved å fange opp spor som kan brukes for å skape mentale bilder av personene, miljøet og situasjonene, og en konnektiv responsform, som innebærer en elaborering av fortellingens verden gjennom å lete etter spor og fylle ut gap i historien. Det er med andre ord responser som legger vekt på personenes mimetiske komponent. J2 gjør imidlertid også flere analytiske observasjoner her, basert på et tydelig individuelt perspektiv, som hun engasjert deler med de andre. Hun åpner også opp for en tentativ interpretativ hypotese, der hun gir uttrykk for normative vurderinger av romanuniversets politiske system. Gjennom tegningen og hennes muntlige formidling av perspektiv, observasjonene og refleksjon, legger J2 til rette for en sekvens der primært J1 følger opp med samtaleresponser som både roser og bekrefter J2s framstilling. De gjennomfører en kort, men substansiell utveksling av tanker om romanpersonenes valgsituasjon. Blant annet trekker de linjer fra personenes livsbetingelser i det daglige og bruken av valgsituasjoner som ledemotiv giennom hele romanen. Dermed løfter de også fram motivets tematiske betydning:

J2: Det er liksom ikke moralen akkurat. Men det ligger liksom litt moral i det liksom.

J1: Det er liksom det - det er det som kommer til å henge igjen etterpå.

J2: Ja. Det er liksom hvilke type valg mennesker har, og hvor mye de bestemmer over seg selv. (CV, samtale 1, 03:13-03:24) 
I sum fører sekvensen dem et skritt nærmere større forståelse for romanens eksistensielle tematikk.

I den andre samtalen fortsetter gruppen med den produktive bruken av rolleark, og presenterer sine roller med rike leseresponser og med et tydelig ønske om å dele dem med hverandre. For eksempel hjelper lysmesterrollen J1 til å finne fram til et meningsbærende avsnitt i narrasjonens etablering av Cassia som opprører og lederfigur. Likedan er illustratørrollen til hjelp for J3. Hun kommenterer selv at hun ikke er så flink til å uttrykke seg muntlig, men gjennom tegningen får hun formidlet sitt perspektiv på et sentralt aspekt ved bokens tematikk.

J3: Ok, jeg tenkte på hvordan det egentlig var der, sant, men så tanken på friheten, så hun trenger ikke være - eh, holde seg inne på selve samfunnet og hva de giør og sånn.

J1: Det synes jeg passer veldig bra til tema på boken. Det var veldig fin tegning, synes jeg.

J3: [ler] Jeg er ikke så god til å si det.

J1: Men jeg fatter det altså sånn at hun er innesperret, sånn som på coveret, der er hun jo inni den der boblen sin.

J3: Ja.

J1: Så ville hun på en måte bryte seg mer og mer ut når hun fatter det mer og mer.

J3: Ja, hun skjønner liksom mer hva samfunnet går ut på, så begynner hun å stille spørsmål med det da. Og så begynner hun å tenke tanken på hvordan det hadde vært å være fri liksom, og gjøre det du vil.

$[\ldots]$

J2: Ja. Hvis du ser på coveret på den første, der hun er inni en sånn boble. Men så går hun litt ut i neste bok.

J1: $\quad$ Mm.

J2: Og så i den siste boblen er hun helt ute. Jeg tror det er det som liksom ligger bak i alle tre bøkene.

J1: Ja.

J2: Det at hun kommer seg mer og mer ut og giør mer og mer opprør.

$\mathrm{J} 1$ : Og får mer og mer frihet, liksom.

J2: $\quad$ Mm. Så det er jo veldig kult da. (CV, samtale 2, 04:22-06:44)

Tegningen fører til substansiell oppfølging, der J1 og J2 både gir positiv tilbakemelding og verbaliserer den tolkningen tegningen formidler. Slik giør de det også lettere for J3 å utdype tolkningen verbalt, der hun også forsøker å sette seg inn i den tilstanden av ufrihet som blir beskrevet i romanen, og viser på den måten innlevelse og empati. Igjen ser vi hvordan en tegning åpner opp for en utforskende sekvens, fordi den gjør det enklere for en elev å formidle leseresponsen sin og for andre å utforme substansiell samtalerespons. Den dialogiske utvekslingen innebærer også ny innsikt og økt felles forståelse i form av en mer helhetlig tolkning av teksten.

Når tredje samtale starter, har alle tre lest ferdig boken, og det blir en samtale som i stor grad handler om hva som kommer til å skje i etterkant av historien, og kanskje da videre $i$ trilogien. Bare helt innledningsvis finner vi en kort utforskende sekvens, innledet av J2 som, i rollen som lysmester, løfter fram et meningsbærende avsnitt og reflekterer nokså grundig over romanens sosialfilosofiske tematikk. Denne åpningen fører til 


\section{A. Hennig}

en kort diskusjon (halvannet minutt) om balansegangen mellom frihet og trygghet som sosial kontrakt. Resten av samtalen består av kortere sekvenser som for så vidt er utforskende, men der de forsøker å få et bedre bilde av noen sentrale hendelser i romanen i tillegg til å spekulere på fortsettelsen. Det vil si at det er sekvenser der de utvider og utfyller sine etablerte forestillingsverdener. De utvider slik sett opplevelsen og forståelsen av romanen på handlingsplan, men i mindre grad på et tematisk plan.

En årsak til at det er såpass god flyt i de tre samtalene, inkludert relativt lange sekvenser av mer eller mindre utforskende karakter, er elevenes samtaleferdigheter. Ikke minst har alle samtalene jevnlige innslag av både generell og mer spesifikk positiv respons, og av at jentene inviterer hverandre inn i samtalen. De gir hverandre små bekreftelser i form av for eksempel «ja» eller «mm», som også er med på å legge et grunnlag for mer substansielle replikkvekslinger. Dette er verbale handlinger som blant annet er et resultat av at opplæringen inkluderte miniforelesninger om og modelleringer av oppmerksom lytting og aktiv respons. Samtidig er det handlinger som viser både evne og vilje til å innta hverandres perspektiver, og som indikerer forsøk på å nå en form for felles fundament for videre utforsking av teksten.

\section{Sangen om en brukket nese}

Felles for de tre første samtalene om romanen Sangen om en brukket nese er at de begynner mer monologisk. Trolig har det sammenheng med bruken av rolleark. Disse gir en trygg og for så vidt effektiv vei inn i samtalene. Det ser også ut til å fungere produktivt i den forstand at de tre guttene innleder med nokså rike leseresponser. Derimot er de, hver for seg, mest opptatt av å presentere disse leseresponsene, og er derfor øyensynlig mindre innstilt på å respondere på hverandres innspill. Men samtalene har også det til felles at det ikke varer veldig lenge før oppmerksomheten vendes vekk fra egne til de andres presentasjoner. I den første samtalen giør for eksempel lysmesteren G1 flere observasjoner som åpner for en sekvens med utveksling av responser orientert mot forbindelser på romanens handlingsplan.

G1: Ja, jeg også trodde det. Men altså et viktig avsnitt er også når, eh - jeg vet ikke - avsnittet: «Jeg tror mamma ønsker seg en tøffere sønn. For senere i livet kommer du til å takke meg for det, pleier mamma å si.» Dette er hovedgrunnen for at han bokser, og derfor tror jeg - synes jeg dette er et viktig, eh - viktig avsnitt da. Og det er kanskje et frampek, fordi moren sier senere $\mathrm{i}$ livet liksom, at han kommer til å takke henne for det.

G2: Ja.

G1: Og da er det frampek, liksom.

G2: Hun vet han kommer til å bli mobbet på ungdomsskolen, liksom.

G1: Ja. Et annet viktig avsnitt er - «Det er få ting som er sikkert her i livet. Her er en av de. Jeg skal ikke gjøre noe som helst på sommerfesten.» Dette er et frampek da, til sommerfesten, liksom.

G2: $\mathrm{Mm}$.

G1: Og så er det viktig [...] eh -

G2: Jeg tipper at han kommer til å gjøre noe på sommerfesten. (SBN, samtale 1, 03:13-04:08) 
Beveggrunnene G1 her tillegger hovedpersonen, viser fram til en sentral tematisk tråd gruppen vil forfølge senere i samtalene. Han gjør altså analytiske observasjoner relatert til hovedpersonens mimetiske komponent, som også har implikasjoner for en tolkning av hovedpersonens tematiske komponent. G2 følger opp med konkretiseringer av det han anser som en sannsynlig framtid for hovedpersonen. Dette er ytringer som kan være basert både på personlige erfaringer og ikke minst på erfaringer fra liknende tekster fra fritidskulturen, men som uansett markerer en tydelig forventning til hvordan handlingen skal utvikle seg. Slike proleptiske spekulasjoner er også basert på guttenes empatiske opplevelse av hovedpersonen Barts sosiale og emosjonelle situasjon og på deres felles elaborerende utvikling av en forestillingsverden. Denne prosessen innebærer blant annet at de forsøker å sette seg selv i Barts sted, for eksempel i konkrete situasjoner eller med hensyn til hans mer generelle livssituasjon. Sentralt i samtalene er da særlig Barts konstante mangel på mat. Det er kanskje ikke så underlig, når gruppen består av tre gutter på 14 år.

I den andre samtalen nærmer vi oss fire minutter før denne vendingen finner sted. Da legger G3, som illustratør, fram en tegning av den alkoholiserte og overvektige moren til Bart og av den rotete leiligheten deres. Dette ansporer en sekvens der elevene utveksler og vurderer perspektiver på morens tilstand og innstilling og på følgene dette får for Bart.

G3: Jeg er illustratør og det første jeg tegnet var moren som sitter på sofaen med mye mat og - og sånn skrot rundt seg. Det var slik jeg tenkte at huset deres så ut. Og det var jo det som fikk henne til å gå til -

G1: [overlappende] Ja, jeg kan tenke meg at hun ser slik ut liksom, fordi-

G3: Ja.

G1: Hun virker veldig lat. Hun bor jo nesten i den sofaen, liksom.

G2: [uklart] alkoholiker -

G1: [ler litt]

G3: Ja, og så ser det ut som at hun drikker ganske mye hjemme.

G1: Se, hvis du [uklart] før liksom - det sto jo i boken at det skjedde sjeldnere og sjeldnere, liksom. Så - det er kanskje en grunn til at hun ikke jobber så mye, heller. At hun er alkoholiker.

G3: Og denne gangen var det sånn at doktoren sa at hun måtte slutte å - ja, drikke, ellers så kunne hun dø. Så skal hun ha sånn slanke-, sånn der - eh operasjon.

G1: Slanke - slankeoperasjon, ja.

G3: Ja, og så sa han at hun måtte gå mye mer. Hun måtte ikke bare ligge hele dagen i sofaen.

G1: Ja.

G3: Hun kunne nesten ikke gå til butikken. Han der Bart måtte gå om natten også. Selv om han var redd, liksom, så gikk han om natten. Så pleide han ofte å være hjemme. (SBN, samtale 2, 03:28-04:40)

G3s empatiske lesemåte og personlige respons på tekstens mer underliggende emosjonelle aspekter er påfallende. Han reagerer ikke bare med indignasjon eller harme på morens tilstand, men ser situasjonen fra Barts perspektiv. Han opplever Barts engstelse for at moren skal dø, bekymringen over tilgangen til mat eller også det 


\section{A. Hennig}

skremmende ved å befinne seg alene ute om natten. Og hans forståelse for det traumatiske i Barts situasjon danner et mønster i alle samtalene. Flere steder poengterer han den alltid truende sulten, savnet etter en far og behovet for trygget og trøst som bestemoren og den forsofne narkomane Geir kan tilby i beskjedne doser. Bart er for øvrig selv en omsorgsfull person, som bekymrer seg for både Geir, bestemoren og den underlige "erstatningsfaren» John Jones, som han etter hvert blir kjent med. Slik kan man hevde at G3 så å si speiler seg i Barts empatiske framtoning. Det kan være noe av årsaken til at hans omsorgsfulle interesse for Barts situasjon og framtid preger samtalene. For eksempel kan han, som her, innlede en sekvens der guttene utforsker grundigere forholdet mellom Bart og moren. Eller så kan innspillene hans påvirke en allerede etablert sekvens, for eksempel der de diskuterer hvordan det vil gå videre med Bart og moren, og han ytrer et sterkt og detaljert utformet ønske om at moren vil endre livsstil for å giøre Barts situasjon enklere.

Denne empatiske tilnærmingen påvirker også samtalen når guttene diskuterer et sentralt handlingsdrivende element i romanen, nemlig Barts manglende far. Særlig interessant er en sekvens som innledes ved at G3 knytter en nærliggende intertekstuell referanse til utforskingen av innvirkningen den fraværende faren har på Barts situasjon og tilstand:

G3: Ja, jeg er da forbinder. Og jeg fant ikke mange ting jeg kunne forbinde dette med. Men jeg forbandt det med Billy Elliot som vi så på skolen. Jeg forbandt det med Billy Elliot fordi de er jo litt like. De passer ikke så veldig mye inn, og Billy Elliot - moren hans er jo død da. Og Bart sin far er - han vet ikke hvem som er faren hans. Så begge har bare én forelder. Og Bart - begge pleide å gå på boksing. Men Bart - Bart vil heller synge. På slutten av boken sier han at han heller vil bruke ti tusen timer på å synge enn å bruke ti tusen timer på å - eh -

G1: Bokse

G3: På å bokse. Og Billy Elliot vil jo heller gå på ballett enn å bokse. I boken så leier jo moren en film som heter Billy Elliot, og det er jo den samme. Men jeg tror også det handler om boksing, men - den handlet egentlig om en gutt som heller ville gå på ballett.

G1: Ja. Men det der du sa om ti tusen timer med synging og ti tusen timer med boksing. Han besøkte jo han der operasangeren.

G3: Ja.

G1: Og da sa han - og da spurte han der operasangeren sånn; vil du synge eller vil du bokse. Og da tar liksom Bart et viktig valg i teksten da.

G3: Ja.

G1: Men han - jeg tror at han alltid har likt sang bedre enn boksing. (SBN, samtale 3, 01:57-03:35)

Litt tilfeldig har guttene valgt en roman der hovedpersonen ser en film som de selv har sett på skolen for ikke så veldig lenge siden. Arne Svingen skriver jo inn denne referansen fordi filmen og romanen har flere sammenfallende motiver og tematikker. Samtidig giør forbinderrollen det enda mer naturlig at G3 løfter fram akkurat denne relasjonen, som åpner opp for en sekvens der guttene utforsker forholdet mellom fraværende foreldre og den sårbare situasjonen dette setter et barn i. De poengterer også 
hvordan barn må giøre noen grunnleggende valg i de komplekse overgangene til en mer identitetsbevisst ungdomstid. Samtidig antyder G3 at slike valgsituasjoner også er et forventet element i ungdomsromaners narrative struktur. Sekvensen viser resultatet av en kombinasion av elevers lesing av tekster med appell og litteraturdidaktiske tilnærmingsmåter som hjelper eleven til å registrere og sette ord på forestillingsverdenene de skaper og observasjonene de gjør i teksten. Kombinasjonen skaper nye muligheter for utveksling av lese- og samtaleresponser, og følgelig for ny innsikt om både teksten og verden.

På liknende vis åpner spørsmålsstillerens (G2) spørsmål om hvorfor moren til Bart havner på sykehus, en sekvens der gruppen særlig elaborerer forhold rundt morens tilstand.

G2: Ja, jeg er spørsmålsstiller. Hvorfor må moren dra til sykehuset?

G1: Fordi hun gikk seint ut - eh - Hun skulle bare ut på en liten tur, da. Og så kom hun aldri hjem, og så hadde hun drukket alt for mye. Og så - og så sier bestemoren at det er enda verre, siden hun har diabetes og $[\ldots]$

G1: Ja, jeg følte vel at Bart tar litt mer ansvar enn det moren gjør.

G3: Ja.

G1: For eksempel i stedet for McDonalds så kjøper han liksom pålegg og -

G2: Ja, hun må liksom si til han at han skal kjøpe - men det er han som -

G2: Han får ikke ansvar, men han tar ansvar.

G1: Ja, han tar ansvar da. Men han sa liksom at hvis - hvis han hadde blitt tatt av barnevernet, så hadde ikke moren klart det liksom. Så det sier litt om hvem Bart er, liksom, og han hjelper moren og -

G2: Moren ødelegger jo for livet til Bart.

G1: Ja, det er - det er -

G3: Han må jo liksom se over henne. Han - i starten av boken så står det at han måtte legge seg etter at hun hadde lagt seg, selv om han skulle på skolen dagen etter, antakeligvis syv da, eller våkner opp syv. Sånn som på barneskolen.

$[\ldots]$

G1: Ja, hun må giøre noe med livet. Hun kan ikke bare liksom synes synd på seg selv. Ja, har du et annet spørsmål G2? (SBN, samtale 2, 08:20-11:19)

De gjør en rekke tekstinterne forbindelser, der de knytter morens innleggelse og hennes alkoholisme til ansvaret som blir pålagt Bart og de praktiske oppgavene han må ta på seg, slik som å skaffe sunnere mat og sørge for at moren kommer i seng. Disse forbindelsene åpner også for refleksjoner over den vedvarende engstelsen Bart opplever, særlig med hensyn til hvordan det skal gå med dem begge, men særlig med moren, ikke minst hvis barnevernet intervenerer og skiller dem. Guttene aktiverer også normative responser, med ønsker for Barts framtid, og gir uttrykk for kritikk av morens atferd og har innspill om hva hun burde giøre. Alt dette skjer i den samme formen for sømløs utforskende utveksling av lese- og samtaleresponser. Sekvensen er også preget av stort engasjement, karakterisert av interesse både for tekstens form og ikke minst for tekstens innhold og for personen de kan relatere seg tydeligst til. 


\section{A. Hennig}

Spørsmålsstiller G2 viser i det hele tatt godt analytisk blikk. Han stiller en rekke spørsmål som, på samme måte som her, åpner opp for interpretatoriske refleksjoner. For eksempel innleder et spørsmål om hvorfor Bart får ny telefon en sekvens med utforsking av Barts situasjon og karakter, som blant annet inkluderer en tolkning av Barts optimistiske natur og en avklaring av hva han har og hva han kan. Et spørsmål om hvorfor Bart blir «bokset i trynet» innleder en sekvens med refleksjoner om Barts personlige utvikling, mens et spørsmål om hvorfor Bart og moren er så redd for barnevernet innleder en sekvens med en ny utforsking av Barts situasjon og karakter, om hvilke materielle utfordringer han opplever, om morens omsorgssvikt og om Barts kreativitet og løsningsorientering.

En interessant utforskende sekvens i den tredje samtalen tar utgangspunkt i lysmesterens betoning av et avsnitt som beskriver Barts mor på sykehuset, som fører til en refleksjon over hvordan bestemoren går inn i den rollen moren egentlig skulle hatt. Samtidig poengterer de sterkt at Bart trenger en slik erstatningsmor. De setter seg inn i Barts situasjon, og G3 stiller det identifikasjonskonstituerende spørsmålet om hvem de andre ville bodd hos, hvis de var Bart, moren eller bestemoren. De diskuterer også bestemorens ambivalens, slik de forstår den som en blanding av på den ene siden omsorg for Bart og bekymring for situasjonen hans, og på den andre siden dårlig samvittighet på bakgrunn av hennes egen omsorgssvikt overfor Barts mor. Guttene berører her en sentral tematikk i romanen. Det er imidlertid ikke en tematikk som blir åpenbart betonet, men som blir antydet gjennom morens speiling av bestemoren. $\AA$ løfte fram denne tematikken innebærer med andre ord en tolkning basert på analytiske observasjoner de drøfter i løpet av samtalen.

Slike sekvenser som inkluderer tolkninger av romanens tematikk, dominerer likevel ikke samtalene. Særlig de to siste samtalene består i større grad av flere sekvenser med engasjert post-narrativ meddikting, der de diskuterer mulige fortsettelser av historien etter at romanen er avsluttet. De gjør det imidlertid med en intens nærhet til historien, som om de fiktive personene var virkelige. De spør seg ikke hvordan fortellingen om Bart kunne blitt videreutviklet som litterær fortelling. De lurer derimot på hvordan det vil gå videre med Bart, moren og andre, og gjennom engasjert utveksling av responser utvikler de stadig rikere forestillingsverdener. Påfallende er det da at de ser for seg at det vil ordne seg for Bart og moren. De vil få råd til å bo «en finere plass der det ikke er så mange narkomane» (G2, SBN, samtale 3, 1.07). Ikke minst legger de vekt på at moren vil ta seg sammen: «Og moren kommer til å slutte å gå ut på pub og sånn. Hun kommer til å ta mer ansvar, og lage mer mat. Og leve sunnere og sånn.» (G3, SBN, samtale 3, 1.09). Denne engasjerte innlevelsen bør forstås som en styrke ved samtalene, og gienspeiler essensen $i$ litterær lesing. Også disse guttene vet selvsagt at det ikke finnes noen virkelige personer i litterær fiksjon, bare ord og en simulering $i$ ord av imaginære personer. Like fullt finner de det vanskelig, som vanlig er for en engasjert leser, å la være å tenke på og snakke om personene i fiksjonen som om de var virkelige mennesker. 


\section{Noen konkluderende merknader}

Sekvensene av utforskende dialog i disse samtalene er i første instans et resultat av elevenes innlevelse i sine valgte romaner, karakterisert av identifikasion med hovedpersonene og interesse for historienes sentrale spenningsskapende momenter. Oppmerksomheten til elevene er slik sett rettet mot personenes mimetiske komponent. Det er verken overraskende eller unaturlig. Å lese prosafiksjon skikkelig er, som J. Hillis Miller understreker, å tillate seg selv både å bli inntatt av personene, å tenke på dem og å snakke om dem som virkelige personer (Miller, 1992, s. 116). Prosafiksjonens fascinasjon stammer nettopp fra produksjonen av sterke illusjoner om en intim tilgang til en annen persons sinn og tanke, en form for tilgang som leseren aldri kan ha i det virkelige liv. Litteraturens vesen og tiltrekningskraft ligger med andre ord primært i de fiktive personenes mimetiske komponent, samtidig som en normalt kompetent leser opprettholder bevisstheten om personenes syntetiske komponent. Derfor er forestillingen om at man kan snakke om personer som om de har eksistert når man diskuterer romaner, dypt rotfestet i vestlig kultur (Miller, 1992, s. 29). Det er da også det elevene her giør.

De tildelte rollene tilfører den engasjerte lesingen konstruktivt fokus, og fører etter alt å dømme til flere analytiske observasjoner. Rollene fungerer også produktivt fordi elevene kommer forberedt til samtalene og $i$ all hovedsak presenterer sine leseresponser åpent og inviterende. Med visse individuelle variasjoner i omfang og hyppighet, framsetter alle elevene sine observasjoner og tanker om sider ved teksten. Perspektiver blir lagt på bordet, og blir som regel gjenstand for vurdering og utprøving. Elevene lytter og følger hverandre opp, etter hvert, med samtaleresponser. Mange av disse er enkle bekreftelser, gjerne kombinert med en kort utfylling av det presenterte perspektivet. Andre responser tar form av en mer substansiell oppfølgende refleksion. Disse konstruktive responsformene er blant annet en følge av langsiktig skolering $i$ litterære samtaler som teori og metode, men også et resultat av genuin interesse for og evne til å innta hverandres perspektiver.

Samtalene er imidlertid alle karakterisert av et fravær av svært ulike ståsteder, men snarere preget av forsøk på nå en form for enighet. Samtalene kunne derfor stått i fare for å flate ut, men de drives videre av engasjerte elaboreringer av historien og hovedpersonenes situasjon og tilstand. Selv om samtalenes sekvenser av utforskende dialog i liten grad fører til ny innsikt basert på utvekslinger av sterkt divergerende perspektiver, oppnår elevene ny forståelse for fiksjonens personer som mimetiske størrelser plassert i spesifikke situasjoner med tematiske implikasjoner. Samtidig er intensiteten i de utforskende dialogene avhengig av at elevene finner tekstens tematikk relevant for deres egen livssituasjon. Og vi har sett hvordan tre jentene synes frihetstematikken i Cassias valg er interessant først og fremst fordi den også angår romanens romantiske trekantdrama, mens de tre guttene finner tematiske størrelser som omsorgssvikt, savn, ansvarsfraskriving og barns medbestemmelse interessante fordi romanens framstilling av hovedpersonen Bart giør det mulig for dem å identifisere seg med ham. 


\section{A. Hennig}

I sum ser vi at sekvenser av utforskende dialog i elevenes samtaler om de to ungdomsromanene primært blir initiert gjennom en kombinasjon av elevenes interesse for og innlevelse i de fiktive personenes mimetiske komponent og spenningen romanens historie etablerer, samtidig som både innledningen og utviklingen av samtalene drar veksler på elevenes skolering i litterære samtaler som teori og metode. Selv om ingenting av dette nødvendigvis er veldig overraskende, kan slike observasjoner likevel være nyttige påminninger i vedvarende litteraturdidaktiske diskusjoner om tekstvalg, undervisningsformer og litterær faglighet. Vi har også sett at de utforskende sekvensene blir videreutviklet gjennom utvekslinger av konnektive responser, der elevene gjør både tekstinterne og -eksterne forbindelser i bestrebelsene på å forstå bedre tekstenes framstillinger av sentrale valgsituasjoner. Det vil si at gjennom dialogiske utvekslinger av perspektiver berører elevene også de fiktive personenes tematiske komponent, og løfter personene opp som ideer. Elevene ser ut til å bevege seg mot mer abstrahert forståelse for tematikkene de sentrale valgsituasjonene i romanene bærer fram. Dermed kan man kanskje argumentere for at elevene også oppnår ny innsikt i litterære framstillinger av eksistensielle valg i modningsprosesser til barn og unge, og i valgenes utenomlitterære betingelser, slik de også er eller kan bli aktuelle $i$ elevenes egne liv.

\section{Forfatteromtale}

Åsmund Hennig er førsteamanuensis ved lærerutdanningen ved Universitetet i Stavanger. Den litteraturdidaktiske forskningen hans er primært konsentrert om leselyst, litterære samtaler og barne og ungdomslitteratur.

\section{Referanser}

Allan, J., Ellis, S. \& Pearson, C. (2005). Literature circles, gender and reading for enjoyment [Rapport]. Scottish Executive. http://www.scotland.gov.uk/Resource/Doc/930/0021345.pdf

Allington, R. L. \& Gabriel, R. E. (2012). Every child, every day. Educational Leadership, 69(6), 10-15.

Appleyard, J. A. (1991). Becoming a reader: The experience of fiction from childhood to adulthood. Cambridge University Press.

Atwell, N. \& Merkel, A. A. (2016). The reading zone: How to help kids become skilled, passionate, habitual, critical readers (2. utg.). Scholastic Professional.

Daniels, H. (2002). Literature circles:Voice and choice in book clubs and reading groups. Stenhouse Publishers.

Department for education. (2012). Research evidence on reading for pleasure. https://www.gov.uk/government/ publications/research-evidence-on-reading-for-pleasure

Edmunds, K. M. \& Bauserman, K. L. (2006). What teachers can learn about reading motivation through conversations with children. The Reading Teacher, 59(5), 414-424. https://doi.org/10.1598/RT.59.5.1

Gambrell, L. B. (2011). Seven rules of engagement: What's most important to know about motivation to read. Reading Teacher, 65(3), 172-178. https://doi.org/10.1002/TRTR.01024

Hennig, Å. (2019). Lydopptak i litterære samtaler: Litteraturdidaktiske muligheter og utfordringer. I D. Husebø, M.-A. Igland \& A. Skaftun (Red.), Ny hverdag? Literacy-praksiser i digitaliserte klasserom på ungdomstrinnet. Universitetsforlaget.

Ivey, G. (2014). The social side of engaged reading for young adolescents. The Reading Teacher, 68(3), 165-171. https://doi.org/10.1002/trtr.1268

Langer, J. A. (1995). Envisioning literature: Literary understanding and literature instruction. Teachers College Press. 


\section{Utforskende dialoger om to ungdomsromaner}

Mercer, N. (2000). Words and minds: How we use language to think together [Samtaler, Ebrary]. Routledge. http:// site.ebrary.com/lib/alltitles/docDetail.action?docID=10054095

Miller, J. H. (1992). Ariadne's thread: Story lines. Yale University Press.

Phelan, J. (1989). Reading people, reading plots: Character, progression, and the interpretation of narrative. University of Chicago Press.

Phelan, J. (1996). Narrative as rhetoric: Technique, audiences, ethics, ideology. Ohio State University Press.

Pierce, K. M. \& Gilles, C. (2008). From exploratory talk to critical conversations. I N. Mercer \& S. Hodgkinson (Red.), Exploring talk in schools: Inspired by the work of Douglas Barnes. Sage.

Probst, R. E. (2004). Response and analysis: Teaching literature in secondary school (2. utg.). Heinemann.

Rosenblatt, L. M. (1995). Literature as exploration (5. utg.). Modern Language Association of America.

Sanden, S. (2012). Independent reading: Perspectives and practices of highly effective teachers. Reading Teacher, 66(3), 222-231. https://doi.org/10.1002/TRTR.01120

Wilhelm, J. D. (2008). You gotta be the book: Teaching engaged and reflective reading with adolescents (2. utg.). Teachers College Press: National Council of Teachers of English.

Wilhelm, J. D. \& Novak, B. (2011). Teaching literacy for love and wisdom: Being the book and being the change. Teachers College Press. 